\title{
Vicia faba agglutinin, the lectin present in broad beans, stimulates differentiation of undifferentiated colon cancer cells
}

\author{
M Jordinson, I El-Hariry, D Calnan, J Calam, M Pignatelli
}

\begin{abstract}
Background-Dietary lectins can alter the proliferation of colonic cells. Differentiation is regulated by adhesion molecules which, being glycosylated, are targets for lectin binding.

Aims-To examine the effects of dietary lectins on differentiation, adhesion, and proliferation of colorectal cancer cells.

Methods-Differentiation was assessed in three dimensional gels, adhesion by aggregation assay, and proliferation by ${ }^{3} \mathbf{H}$ thymidine incorporation. The role of the epithelial cell adhesion molecule (epCAM) was studied using a specific monoclonal antibody in blocking studies and Western blots. The human colon cancer cell lines LS174T, SW1222, and HT29 were studied.

Results-The cell line LS174T differentiated in the presence of Vicia faba agglutinin (VFA) into gland like structures. This was inhibited by anti-epCAM monoclonal antibody. Expression of epCAM itself was unaffected. VFA as well as wheat germ agglutinin (WGA) and the edible mushroom lectin (Agaricus bisporus lectin, ABL) significantly aggregated LS174T cells but peanut agglutinin (PNA) and soybean agglutinin (SBA) did not. All lectins aggregated SW1222 and HT29 cells. Aggregation was blocked by the corresponding sugars. Aggregation of cells by VFA was also inhibited by anti-epCAM. VFA, ABL, and WGL inhibited proliferation of all the cell lines; PNA stimulated proliferation of HT29 and SW1222 cells. In competition studies all sugars blocked aggregation and proliferation of all cell lines, except that the addition of mannose alone inhibited proliferation.

Conclusion-VFA stimulated an undifferentiated colon cancer cell line to differentiate into gland like structures. The adhesion molecule epCAM is involved in this. Dietary or therapeutic VFA may slow progression of colon cancer.

(Gut 1999;44:709-714)
\end{abstract}

Keywords: lectins; differentiation; proliferation; polarity; colon cancer

Colorectal cancer is the second most common cause of cancer death in Britain and we are therefore looking for factors which might prevent or treat it. Lectins are plant proteins that bind to specific carbohydrate motifs. ${ }^{1}$
They are abundant in the $\operatorname{diet}^{2}$ resist digestion, ${ }^{34}$ remain active in the colon, ${ }^{56}$ and notably affect the function of gastrointestinal cells. $^{58}$ The group led by Rhodes showed that peanut lectin increases proliferation of the colonic mucosa and postulated that the binding of some lectins to genetically determined sugar motifs may stimulate the development of colorectal tumours. ${ }^{9}$ The same group has recently shown that peanut ingestion increases rectal proliferation in individuals with mucosal expression of peanut lectin receptor Gal $\beta_{1-3}$ Gal Nac- and suggests that this could be an important mechanism for the association between diet and colorectal cancer. ${ }^{10}$ However, a high intake of vegetables, and therefore of lectins, actually decreases the likelihood of colorectal cancer. ${ }^{11}$ Indeed some dietary lectins inhibit proliferation of colorectal carcinoma cell lines. ${ }^{12}{ }^{13}$ Although the proliferative effects of dietary lectins on various colorectal carcinoma cell lines are well documented, ${ }^{71}{ }^{15}$ their effects on differentiation of these cells are relatively unexplored. This is important because the loss of differentiation and invasion are the histological hallmarks of malignant cells. Therefore, we studied the effects of a panel of dietary lectins which bind to different sugar motifs on the differentiation, adhesion, and proliferation of human colon cancer cells. With regard to potential mechanisms, differentiation is regulated by cell adhesion molecules ${ }^{16}$ which are glycosylated and are therefore potential targets for lectin binding. The possible role of adhesion molecules was investigated using a monoclonal antibody against epithelial cell adhesion molecule (epCAM), epithelial cadherin ( $\mathrm{E}$ cadherin), and carcinoembryonic antigen (CEA). We report here that Vicia faba agglutinin (VFA), the lectin present in broad beans, which binds to mannose and glucose reverses the malignant phenotype of these cells, possibly through an interaction with epCAM.

\section{Materials and methods}

All lectins and chemicals were purchased from Sigma Chemical Co (Dorset, UK) unless otherwise stated. SBA, PNA, ABL, VFA, and WGA were tested. Colorectal adenocarcinoma derived cell lines LS174T, ${ }^{17}$ SW1222, and HT2 $29^{18}$ were maintained in Dulbecco modified

Abbreviations used in this paper: $\mathrm{ABL}$, Agarcius bisporus lectin; CEA, carcinoembryonic antigen; E cadherin, epithelial cadherin; epCAM, epithelial cell adhesion molecule; PNA, peanut agglutinin; SBA, soybean agglutinin; VFA, Vicia faba agglutinin; WGA, wheat germ agglutinin. 
Eagle medium (DMEM) containing 10\% fetal calf serum (FCS) at $37^{\circ} \mathrm{C}$ in $90 \% \mathrm{O}_{2}$ and $10 \%$ $\mathrm{CO}_{2}$. Monoclonal antibodies AUA1 to epCAM and PR3B10 to CEA were kindly donated by Sir Walter Bodmer. Antibody HECD-1 to E cadherin was kindly donated by $M$ Takeichi (Kyoto, Japan).

CELL-CELL ADHESION

Confluent cells were detached with $2 \mathrm{mM}$ EDTA, washed in DMEM, and suspended in DMEM $/ 0.8 \%$ FCS. Cells $\left(5 \times 10^{4}\right.$ cells $\left./ \mathrm{ml}\right)$ were allowed to aggregate for one hour at $37^{\circ} \mathrm{C}$ in the presence of lectins $(10 \mu \mathrm{g} / \mathrm{ml})$ on a gyratory shaker; remaining single cells were counted using a Coulter counter (Coulter Electronics, Inc.). Results were divided by the initial single cell count to give an aggregation index. In some studies haptenic sugars (50 $\mathrm{mM}$ ) were added, in others monoclonal antibodies $(50 \mu \mathrm{g} / \mathrm{ml})$ were added to cells 30 minutes before initiating the assay, and in others DMEM was replaced with calcium free PBS. The extent of inhibition was expressed as percentage inhibition of the change in aggregation index produced by the lectin.

WESTERN BLOTTING

Cells were grown in the presence of PNA, SBA, ABL, WGA, and VFA $(10 \mu \mathrm{g} / \mathrm{ml})$ for 48 hours in $140 \mathrm{~mm}$ dishes. Cells were washed in ice cold phosphate buffered saline (PBS) containing the lectin specific haptenic sugars $(5 \mathrm{mM})$ and scraped into $1 \mathrm{ml}$ of sample buffer $(2 \%$ sodium dodecyl sulphate (SDS), 10\% glycerol, 5\% 2-mercaptoethanol, $60 \mathrm{mM}$ Tris- $\mathrm{HCl}, \mathrm{pH}$ 6.8 ), and heat denatured for 10 minutes. Samples were clarified by centrifugation at $13000 \mathrm{~g}$ for 10 minutes at $4^{\circ} \mathrm{C}$, and the total protein concentration was quantified using the Bio-rad (Hertfordshire, UK) protein assay kit. Equal amounts of protein $(30 \mu \mathrm{g})$ were then loaded and resolved by SDS polyacrylamide gel electrophoresis (SDS-PAGE) on $8 \%$ polyacrylamide gel. Resolved proteins were transferred by electroblotting onto nitrocellulose membranes (Millipore, UK). Non-specific binding was blocked with $5 \%$ non-fat dried milk in TBS-T (25 mM Tris-HCl, pH 7.4, $150 \mathrm{mM}$ $\mathrm{NaCl}, 0.5 \%$ Tween 20 ) for two hours at room temperature, and then incubated overnight with AUA-1 antibody as neat supernatant. Membranes were incubated with horseradish peroxidase conjugated antimouse antibodies $(0.5 \mathrm{mg} / \mathrm{ml})$ (Dako, UK) for one hour at room temperature. After extensive washing, membranes were reacted for one minute with enhanced chemiluminescence reagent (ECL) (Amersham, UK) and exposed to hyperfilm-MP film (Amersham, UK).

\section{CELL PROLIFERATION}

Harvested cells were plated into 96 well plates at an initial density of $2 \times 10^{4}$ cells/well in DMEM $/ 10 \%$ FCS or $2 \%$ for ABL due to fetuin being present in the FCS. Cells were allowed to attach overnight and were then incubated for 24 hours in fresh serum free medium. Complete medium contained lectin to a final concentration of 1,10 , or $100 \mu \mathrm{g} / \mathrm{ml}$.
In competition studies the effects of the specific haptenic sugar $(50 \mathrm{mM})$-SBA $(N-$ acetylgalactosamine), PNA (galactose); ABL (fetuin), WGA (N,Ní,Nií-triacetylchitotriose), and VFA (mannose)-for each lectin was tested in the presence and absence of the lectin. All sugars were added to the wells prior to the addition of lectin. After incubating for a further 48 hours, ${ }^{3} \mathrm{H}$ thymidine $(2 \mu \mathrm{Ci} /$ well $)$ was added for a further eight hours. Cells were then washed three times with distilled water, and lysed with $200 \mu \mathrm{l}$ of $1 \mathrm{M} \mathrm{KOH}$ for one hour at $37^{\circ} \mathrm{C}$. Samples $(50 \mu \mathrm{l})$ from each well were then mixed with scintillation fluid $(1 \mathrm{ml})$ (Optiphase safe, LKB, Leicester, UK) and counted in a beta scintillation counter (Beckman Instruments, Inc., California, USA) for one minute per sample.

\section{AMINO ACID INCORPORATION}

The protocol was the same as above, except that $1 \mathrm{mCi}{ }^{3} \mathrm{H}$ amino acids (Amersham) was added instead of ${ }^{3} \mathrm{H}$ thymidine. After eight hours, cells were washed three times with 200 $\mu \mathrm{l}$ of Hanks's balanced salt solution (HBSS), followed by $200 \mu \mathrm{l}$ of $10 \%$ trichloroacetic acid and $200 \mu \mathrm{l}$ of methanol. The plate was then allowed to dry at room temperature. Cells were lysed in $200 \mu \mathrm{l}$ of $1 \mathrm{M} \mathrm{KOH}$ and beta radioactivity counted.

\section{DIFFERENTIATION}

Differentiation was studied by culture in three dimensional collagen gels. Briefly, single cell suspensions $\left(2 \times 10^{4} / \mathrm{ml}\right)$ in DMEM with vitrogen 100 (Imperial Laboratories, UK) were allowed to gel for one hour, then DMEM with or without $2 \%$ FCS was added to the gels for 24 hours. Lectins were added in duplicate at 1,10 , and $100 \mu \mathrm{g} / \mathrm{ml}$ with or without $50 \mathrm{mM}$ of their haptenic sugars and replaced every four days for 21 days. Monoclonal antibodies HECD1, PR3B10, and AUA-1 were added in serial dilutions throughout the experiment. Purified mouse immunoglobulins $(50 \mu \mathrm{g} / \mathrm{ml})$ acted as control. Plates were examined daily by phase contrast microscopy to detect glandular structures, defined as organised cell aggregates with central lumen composed of epithelial cells having nuclei polarised towards the basal surface of the cell. Formalin fixed gels were stained with haematoxylin and eosin and alcian blue-periodic acid Schiff (PAS), and photographed.

\section{STATISTICAL ANALYSIS}

Student's $t$ test was used to analyse cell-cell adhesion. Unpaired two sample $t$ tests were used for proliferation studies. If a significant difference was observed between the variances, data were then analysed by the Mann-Whitney test. A result was considered significant when $\mathrm{p}<0.05$.

\section{Results}

MODULATION OF CELL-CELL ADHESION BY LECTINS

Figure 1 shows the effects of lectins on cell-cell adhesion. 

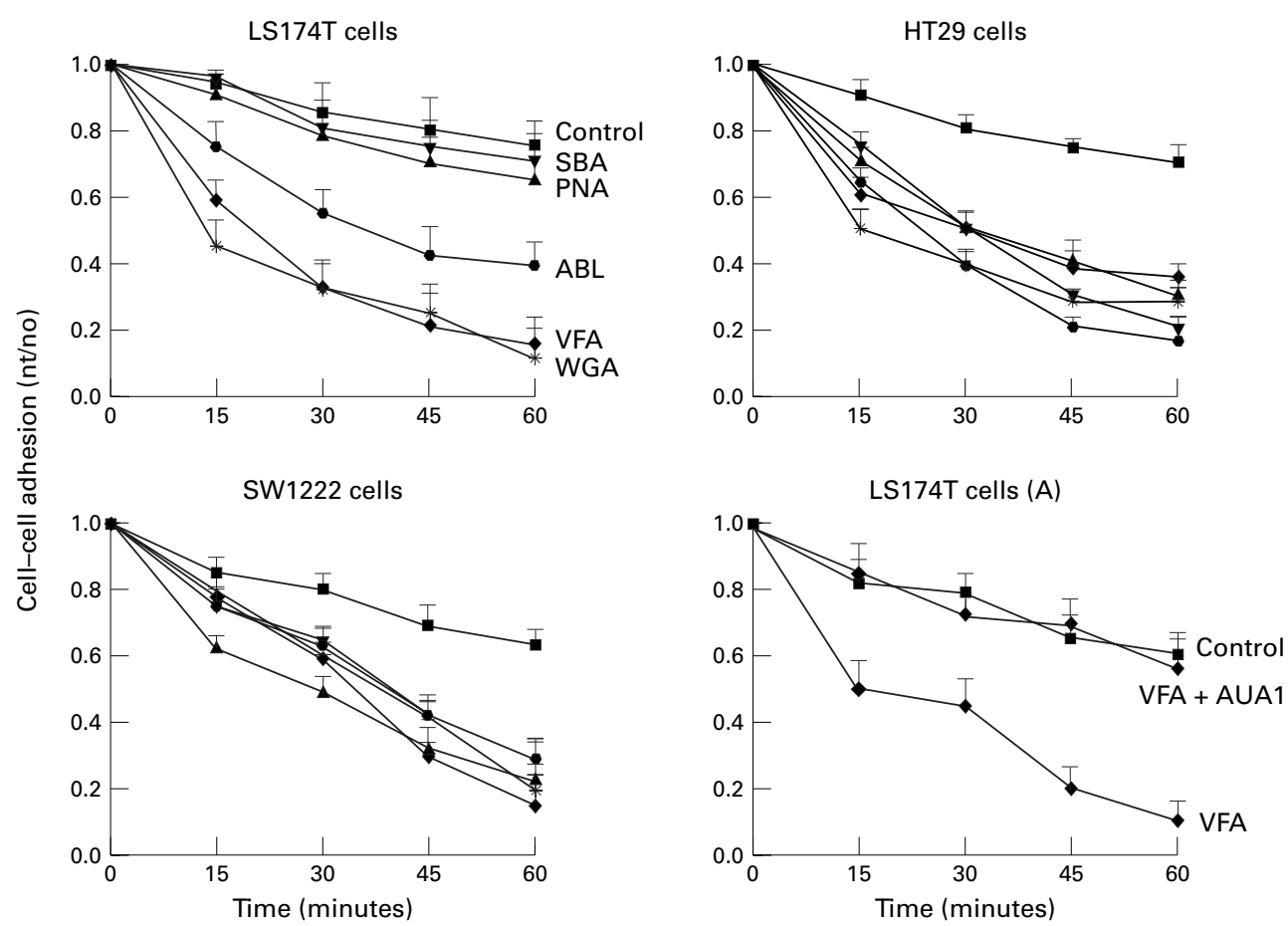

Figure 1 Effects of lectins on cell-cell adhesion of LS174T, SW1222, and HT29 cells. Data represent the mean (SD) of at least three experiments.

LS174T cells-Significant aggregation of LS174T cells occurred following incubation with VFA, WGA, and ABL $(10 \mu \mathrm{g} / \mathrm{ml})$ $(p<0.01)$. Cell-cell adhesion was promoted weakly by PNA and SBA, although the effect was not statistically significant.

HT29 cells-All lectins $(10 \mu \mathrm{g} / \mathrm{ml})$ significantly aggregated HT29 cells compared with control over one hour $(\mathrm{p}<0.01)$.

SW1222 cells-PNA, SBA, ABL, VFA, and WGA $(10 \mu \mathrm{g} / \mathrm{ml})$ significantly aggregated the cells compared with control over one hour $(\mathrm{p}<0.01)$.

Aggregation of all three cell types by lectins was completely blocked by their specific haptenic sugars $(50 \mathrm{mM})$ (data not shown). In addition the response to the lectins did not occur in calcium free medium (data not shown). There was no difference in aggregation by any lectin either in the absence or presence of FCS. Aggregation of LS174T cells by VFA was significantly blocked by monoclonal antiepCAM antibody, AUA-1 ( $\mathrm{p}<0.05)$. However,

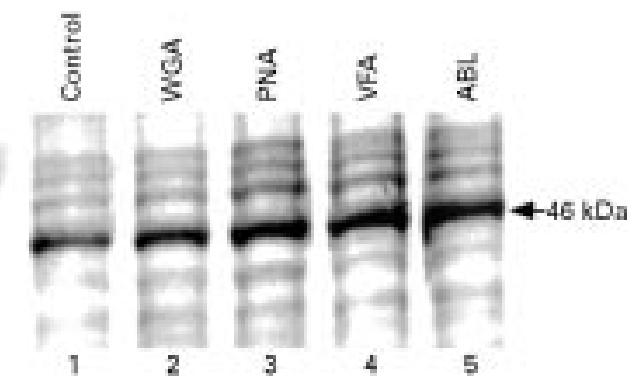

Figure 2 Effect of lectins on the expression of epCAM in the LS174T cells. Cells were serum starved overnight, then fed with fresh medium alone (lane 1) or supplemented with different lectins (VFA, WGA, PNA, SBA, and ABL at 10 $\mu \mathrm{g} / \mathrm{ml})$, and incubated for 48 hours. Molecular weight marker of $46 \mathrm{kDa}$ is indicated by the arrow. antibodies against anti-E cadherin (HECD-1) and anti-CEA (PR3B10) did not block cell aggregation induced by VFA or any other lectin tested.

EFFECT OF LECTINS ON THE STEADY STATE

EXPRESSION OF epCAM

None of the lectins tested had any significant effect on the expression of epCAM in LS174T cells. Immunoblotting detected bands of $(46 \mathrm{kDa})$ of almost equal intensities in both unstimulated and lectin stimulated cells. The blot (fig 2) represents one of three experiments which all gave similar results.

EFFECT OF LECTINS ON PROLIFERATION

Figure 3 shows the effect of lectins on proliferation.

LS174T cells-PNA and SBA $(1,10$, and 100 $\mu \mathrm{g} / \mathrm{ml}$ ) produced a slight increase in thymidine incorporation into LS174T cells. By contrast, VFA and ABL $(1,10$, and $100 \mu \mathrm{g} / \mathrm{ml})$ dose dependently inhibited proliferation of LS174T cells $(\mathrm{p}<0.05)$. WGA $(1,10$, and $100 \mu \mathrm{g} / \mathrm{ml})$ significantly inhibited thymidine incorporation $(\mathrm{p}<0.05)$ but was cytotoxic at $100 \mu \mathrm{g} / \mathrm{ml}$. A lack of cytotoxicity of lectins was also demonstrated by amino acid incorporation. Only VFA $(1,10$, $100 \mu \mathrm{g} / \mathrm{ml}$ ) dose dependently increased amino acid incorporation in LS174T cells.

HT29 cells-VFA and ABL (1, 10, and 100 $\mu \mathrm{g} / \mathrm{ml}$ ) dose dependently inhibited proliferation $(p<0.05)$. Neither lectin was cytotoxic following trypan blue exclusion; although WGA was inhibitory at low concentrations $(p<0.05)$ it was cytotoxic at $100 \mu \mathrm{g} / \mathrm{ml}$ following trypan blue exclusion. In contrast PNA $(1,10$, and $100 \mu \mathrm{g} / \mathrm{ml}$ ) dose dependently stimulated proliferation of HT29 cells $(p<0.05)$. SBA had no significant effect at any concentration. 
Lectin

$\square$ Lectin's specific haptenic sugar

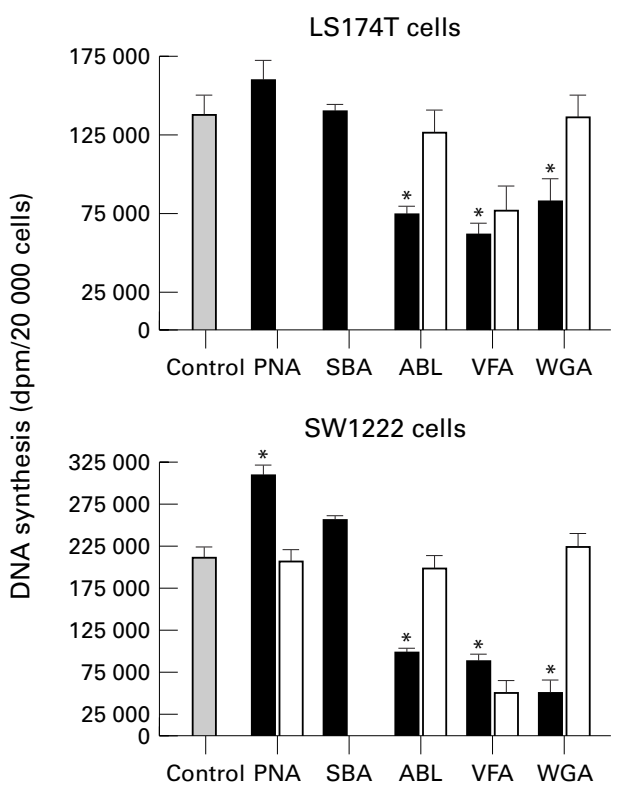

HT29 cells

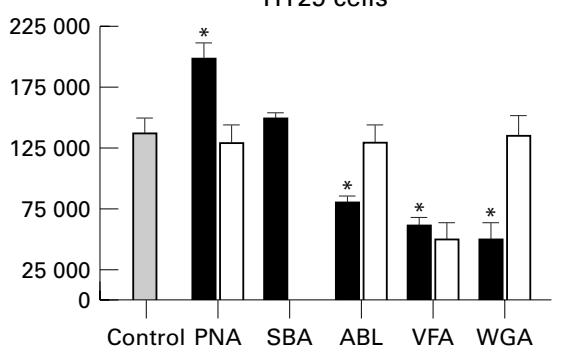

LS174T cells

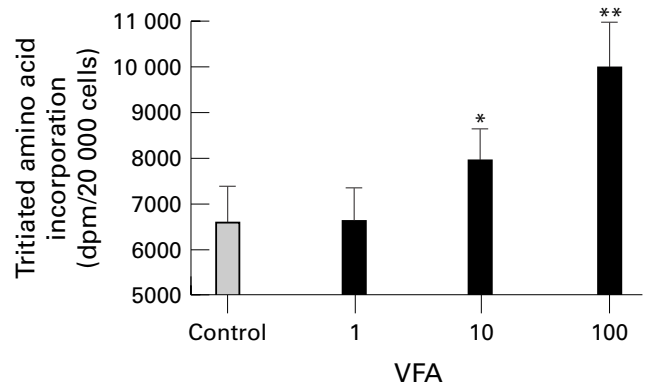

Figure 3 Effect of lectins on cell proliferation of LS174T, SW1222, and HT29 cells. Cells were plated in complete medium alone (control) or supplemented with lectins PNA, SBA, $A B L, V F A$, and $W G A(1,10$, or $100 \mu g / m l)$; and in the presence of the lectins'specific haptenic sugar $(50 \mathrm{mM})$ for 48 hours. VFA $(1,10,100 \mu \mathrm{g} / \mathrm{ml})$ dose dependently increased amino acid incorporation into LS174T cells $(B) .{ }^{\star} p<0.05 ;{ }^{\star}{ }^{\star} p<0.01$. Data represent the means (SD) of triplicate determinations.

SW1222 cells-VFA and ABL $(1,10$, and $100 \mu \mathrm{g} / \mathrm{ml}$ ) dose dependently inhibited proliferation of SW1222 cells ( $\mathrm{p}<0.05)$. WGA (1 and $10 \mu \mathrm{g} / \mathrm{ml}$ ) significantly inhibited proliferation $(\mathrm{p}<0.05)$, and was cytotoxic to the cells at $100 \mu \mathrm{g} / \mathrm{ml}$ following trypan blue exclusion. PNA (10 and $100 \mu \mathrm{g} / \mathrm{ml}$ ) significantly stimulated proliferation $(p<0.05)$ but SBA had no significant effect at any concentration.

In competition studies the effects of lectins on proliferation of all the cell lines were blocked by their specific haptenic sugars (50 $\mathrm{mM}$ ). However, mannose did not reverse the antiproliferative effect of VFA but inhibited proliferation when given alone (data not shown).

EFFECT OF LECTINS ON GLANDULAR DIFFERENTIATION

When grown for two weeks in collagen, LS174T cells formed single disorganised groups of cells and did not show any pattern of glandular differentiation in the presence or absence of FCS (fig 4A). However, when grown in the presence of VFA $(1,10$, and 100 $\mu \mathrm{g} / \mathrm{ml}$ ) with or without FCS, cells showed a tendency to form organised glandular structures consisting of a single layer of cells with basally arranged nuclei around a central lumen containing mucin (fig 4B). This effect was inhibited in the presence of the anti epCAM monoclonal antibody AUA-1 $(50 \mu \mathrm{g} / \mathrm{ml})$ and mannose (not shown). None of the other lectins tested had any significant effect on differentiation of this cell line. There was no significant effect on differentiation in SW1222 or HT29 cells when incubated with lectins.
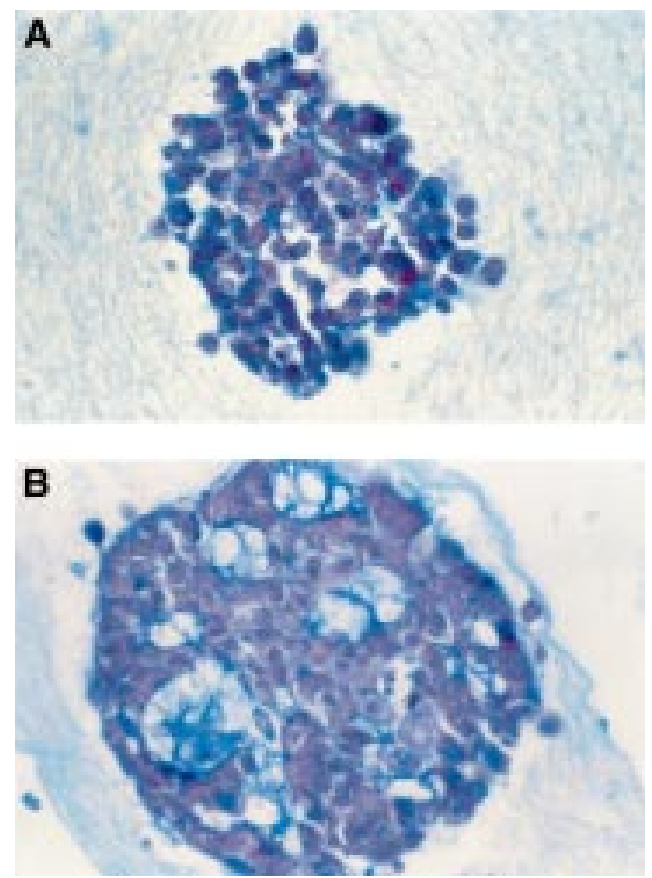

Figure 4 Alcian blue-PAS stained photomicrographs of LS174T cells grown in $3 D$ collagen gels. (A) Control cells grew in amorphous clumps. (B) In the presence of VFA $(10 \mu \mathrm{g} / \mathrm{ml})$ for 14 days the cells grew into gland like structures composed of polarised cells arranged around a central lumen containing mucin.

\section{Discussion}

We have shown for the first time that VFA, the lectin present in broad beans, can increase morphological differentiation and thus diminish the malignant phenotype of colorectal cancer cells. Cell aggregation is necessary for normal colonocyte differentiation ${ }^{19}$ but in the 
present study some lectins also caused aggregation without inducing differentiation. The effect of VFA on cell-cell adhesion of LS174T cells was blocked by monoclonal antibody AUA-1 against epCAM but not by monoclonal antibodies against CEA or E cadherin; this suggests a specific effect on epCAM. No lectin had any significant effect on the expression of epCAM which suggests that VFA acts either by binding directly to epCAM, which is $N$-glycosylated, ${ }^{20}{ }^{21}$ or through a pathway which involves epCAM. It remains to be seen whether VFA binds directly to epCAM.

It is possible that lectins interact with cell surface adhesion molecules in a ligandreceptor fashion, which leads to activation of a signalling pathway. This is supported by the evidence that adhesion molecules participate in a large variety of signal transduction events important for regulating not only cell adhesion but also migration, growth, apoptosis, and specific gene regulation. ${ }^{22}$

It is also possible that VFA may act on a specific cell-surface receptor. In competition studies mannose did not block the effect of VFA on proliferation but when given alone, also dose dependently inhibited proliferation. Growth factor receptors (EGFR) are often glycosylated, and lectins have been shown to bind to them. ${ }^{23}$ Mannose residues are present on the $\mathrm{EGFR}^{24}$ and several mannose binding lectins have been shown to inhibit binding of epidermal growth factor (EGF) to its receptor. ${ }^{25}$ Therefore, mannose may have blocked the effect of endogenous EGF in the medium of the cell lines tested. We have shown previously that transforming growth factor $\alpha$, which is a physiological ligand for the EGF receptor, had a similar effect to VFA on a different colonic epithelial cell line. ${ }^{26}$ Therefore, VFA may mimic the effects of growth factors.

The difference in the cellular response of colorectal carcinoma cell lines to different lectins is consistent with other studies and may reflect differences in the number of lectin binding sites on different colonic cell lines. ${ }^{5}$ WGA binds specifically to sialic acid and GlcNAc and also significantly aggregated the LS174T cells but this was not blocked by monoclonal antibody AUA-1. Although ABL and PNA both bind to Gal $\beta_{1-3}$ Gal Nac-, only $\mathrm{ABL}$ had a significant effect on aggregation of LS174T cells. The difference may reflect the ability of ABL to bind to sialyated $\mathrm{Gal} \beta_{1-3} \mathrm{Gal}$ Nac. ${ }^{12}$ Therefore, binding sites for PNA may have been masked by sialyation. SBA binds to $\mathrm{N}$-acetyl-D-galactosamine and D-galactose; therefore the differences in cell adhesiveness to SBA may reflect the presence or absence of these motifs in these cells.

VFA and ABL dose dependently inhibited proliferation of all cell lines, an effect that was reversible and not associated with cytotoxicity. VFA has previously been shown to inhibit proliferation of Caco-2 cells, ${ }^{13}$ but ABL had no effect on these cells. ${ }^{5}$ Whether this reflects available binding sites for these lectins or differences in their mode of action is still unclear. However, their lack of cytotoxicity suggests a different mechanism of action to that observed with other lectins. Lectin binding epitopes, while essential, are not sufficient for tumour cell lysis because some lectins bind but have no effects. Studies have shown that some lectins are internalised by cells $^{27}$ and trigger apoptosis. ${ }^{28} \mathrm{ABL}$ has also been shown to inhibit proliferation of HT29 cells following internalisation..$^{29}$ Other potential lectin binding sites include glycosylated regions of cell surface adhesion molecules. For example CD44 is the major peanut lectin binding glycoprotein on human epidermal keratinocytes. ${ }^{30}$ WGA binds to the core of CEA whereas concanavalin A (Con A), another mannose/glucose specific lectin, binds to peripheral residues. ${ }^{31}$ WGA also aggregates membrane vesicles through an interaction with the neural cell adhesion molecule (NCAM). ${ }^{32}$

With regard to potential therapeutic effects, VFA is fairly resistant to digestion ${ }^{3} 4$ and was not cytotoxic when fed to animals. ${ }^{33}$ Therefore, VFA appears to be the only known non-toxic dietary lectin other than ABL with inhibitory effects on proliferation. Although there are a limited number of sites for binding of mannose binding lectins in the gastrointestinal tract they have been identified in the proximal but not the distal colon. ${ }^{34}$ However, many more cell surface proteins are $N$-glycosylated and likely to contain some mannose, so the lack of binding of mannose binding lectins is likely to reflect differences in lectin affinity rather than the simple presence or absence of mannose. VFA and other mannose binding plant lectins may contribute to protection from colorectal cancer by vegetables through effects on tumour development. In addition the new data implicating epCAM in the effect suggests a new target through which the behaviour of tumours might be modified. We are currently investigating the effects of VFA and other plant and mammalian mannose binding lectins on the development of gastrointestinal tumours.

We thank the World Cancer research fund and the Wellcome Trust for funding Mark Jordinson. We thank Sir Walter Bodmer for kindly donating AUA-1 and PR3B10 monoclonal antibodies and Professor $M$ Takeichi for providing HECD1 monoclonal antibody.

1 Goldstein IJ, Poretz RD. Isolation, physicochemical characterisation, and carbohydrate-binding specificity of lectins. In: Liener IE, Saron N, Goldstein IJ (eds). The lectins: properties, functions, and applications in biology and medicine. London: Academic, 1986:33-237.

2 Nachbar MS, Oppenheim JD. Lectins in the United States diet: a survey of lectins in commonly consumed foods and a review of the literature. Am f Clin Nutr 1980;33:2338-45.

3 Pusztai A, Ewen SW, Grant G, et al. Relationship between Pusztai A, Ewen SW, Grant G, et al. Relationship between
survival and binding of plant lectins during small intestinal survival and binding of plant lectins during small intestinal
passage and their effectiveness as growth factors. Digestion passage and their effectiven

4 Jordinson M, Playford RJ, Calam J. Effects of a panel of dietary lectins on cholecystokinin release in rats. Am $\mathcal{F}$ Physiol 1997;36:G946-50.

5 Ryder SD, Smith JA, Rhodes JM. Peanut lectin: a mitogen for normal human colonic epithelium and human HT29 colorectal cancer cells. F Natl Cancer Inst 1992;84:1410-16.

6 Brady PG, Vannier AM, Banwell JG. Identification of the dietary lectin, wheat germ agglutinin, in human intestinal contents. Gastroenterology 1978;75:236-9.

7 Ryder SD, Smith JA, Rhodes EGH, et al. Proliferative responses of HT29 and $\mathrm{CaCo} 2$ human colorectal cancer cells to a panel of lectins. Gastroenterology 1994;106:85-93.

8 Ryder SD, Parker N, Ecclestone D, et al. Peanut lectin stimulates proliferation of colonic explants from patin stimulates proliferation of colonic explants from patients with inflammatory bowel diseas

9 Rhodes JM. Unifying hypothesis for inflammatory bowel disease and associated colon cancer: sticking the pieces together with sugar. Lancet 1996;347:40-4. 
10 Ryder SD, Jacyna MR, Levi AJ, et al. Peanut ingestion increases rectal proliferation in individuals with mucosal expression of peanut lectin receptor. Gastroenterology 1998; 114:44-9.

11 Potter JD. Risk factors for colon neoplasia-epidemiology and biology. Eur $\mathcal{F}$ Cancer 1995;31A:1033-8.

12 Yu L, Fernig DG, Smith JA, et al. Reversible inhibition of proliferation of epithelial cell lines by Agaricus bisporus (edible mushroom) lectin. Cancer Res 1993;53:4627-32.

13 Koninkx JF, Hendriks HG, van Rossum JM, et al. Interaction of legume lectins with the cellular metabolism of differentiated Caco-2 cells. Gastroenterology 1992;102: 1516-23.

14 Kiss R, Camby I, Duckworth C, et al. In vitro influence of Phaseolus vulgaris, Griffonia simplicifolia, concanavalin A wheat germ, and peanut agglutinins on HCT-15, LoVo, and SW837 human colorectal cancer cell growth. Gut 1997;40: 253-61.

15 Chen YF, Boland CR, Kraus ER, et al. The lectin Griffonia simplicifolia I-A4 (GS I-A4) specifically recognizes terminal alpha-linked N-acetylgalactosaminyl groups and is
cytotoxic to the human colon cancer cell lines LS174t and SW1116. Int f Cancer 1994;57:561-7.

16 Takeichi M. Cadherin cell adhesion receptors as a morphogenetic regulator. Science 1991;251:1451-5.

17 Rutzky LP, Kaye CI, Siciliano MJ, et al. Longitudinal karyotype and genetic signature analysis of cultured human colon adenocarcinoma cell lines LS180 and LS174T. Cancer Res 1980;40:1443-8.

18 Leibovitz A, Stinson JC, McCombs WB, et al. Classification of human colorectal adenocarcinoma cell lines. Cancer Res 1976;36:4562-9.

19 Pignatelli M, Liu D, Nasim MM, et al. Morphoregulatory activities of E-cadherin and beta-1 integrins in colorectal tumour cells. Br f Cancer 1992;66:629-34.

20 Litvinov SV, Velders MP, Bakker HA, et al. Ep-CAM: a human epithelial antigen is a homophilic cell-cell adhesion molecule. F Cell Biol 1994;125:437-46.

21 Litvinov SV, Bakker HA, Gourevitch MM, et al. Evidence for a role of the epithelial glycoprotein 40 (Ep-CAM) in 417-28.
22 Albelda SM, Buck CA. Integrins and other cell adhesion molecules. FASEB $\mathcal{F}$ 1990;4:2868-80.

23 Carpenter G, Cohen S. Influence of lectins on the binding of 125I-labeled EGF to human fibroblasts. Biochem Biophys Res Commun 1977;79:545-52.

24 Stoscheck CM, Soderquist AM, Carpenter G. Biosynthesis of the epidermal growth factor receptor in cultured human cells. Endocrinology 1985;116:528-35.

25 Zeng FY, Benguria A, Kafert S, et al. Differential response of the epidermal growth factor receptor tyrosine kinase activity to several plant and mammalian lectins. Mol Cell ity to several plant and
Biochem $1995 ; 142: 117-24$.

26 Liu D, Gagliardi G, Nasim MM, et al. TGF-alpha can act as morphogen and/or mitogen in a colon-cancer cell line. Int f Cancer 1994;56:603-8.

27 Goldman R, Sharon N, Lotan R. A differential response elicited in macrophages on interaction with lectins. Exp Cell Res 1976;99:408-22.

28 Kim M, Rao MV, Tweardy DJ, et al. Lectin-induced apoptosis of tumour cells. Glycobiology 1993;3:447-53.

29 Yu LG, Fernig DG, Davies H, et al. Internalization and nuclear incorporation of the growth inhibitory lectin from edible mushroom by HT29 colon cancer cells [abstract]. Gastroenterology 1995;108:A558.

30 Hudson DL, Sleeman J, Watt FM. CD44 is the major peanut lectin-binding glycoprotein of human epidermal keratinocytes and plays a role in intercellular adhesion. $7 \mathrm{Cell} \mathrm{Sci}$ 1995;108: 1959-70.

31 Rogers GT. Carcinoembryonic antigens and related glycoproteins. Molecular aspects and specificity. Biochim Biophys Acta 1983;695:227-49.

32 Rutishauser U, Acheson A, Hall AK, et al. The neural cell adhesion molecule (NCAM) as a regulator of cell-cell interactions. Science 1988;240:53-7.

33 Rubio LA, Grant G, Bardocz S, et al. Nutritional response of growing rats to faba beans (Viciafaba L., minor) and faba bean fractions. Br ₹ Nutr 1991;66:533-42.

34 Boland CR, Martin MA, Goldstein IJ. Lectin reactivities as intermediate biomarkers in premalignant colorectal epithelium. f Cell Biochem Suppl 1992;16G:103-9. 